\title{
ANL/CMT/CP--92525
}

CONF-961202--97

\section{THERMODYNAMIC STABILITIES OF U(VI) MINERALS: ESTIMATED AND OBSERVED RELATIONSHIPS}

\author{
R. J. Finch* \\ University of Manitoba, Winnipeg, Manitoba, R3T 2N2, Canada \\ *Current address: Argonne National Laboratory \\ 9700 South Cass Avenue \\ Argonne, IL 60439 \\ SECENGBD \\ MAR 251997 \\ OSTI
}

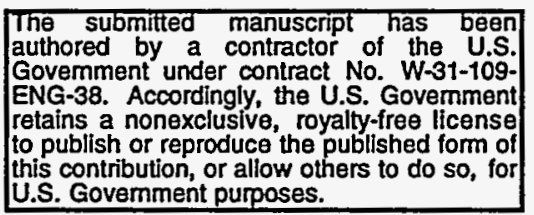

Submitted to

1996 Fall Meeting

Materials Research Society

Boston, MA

December 2-5, 1996

This work was completed at the University of Manitoba during a postdoctoral fellowship from the National Science and Engineering Research Council (Canada). Financial support for the early stages of this work were provided by the Swedish Nuclear Fuel and Waste Management Co. (SKB). Travel funds were provided by the U.S. Department of Energy, under contract W-31-109-ENG-38.

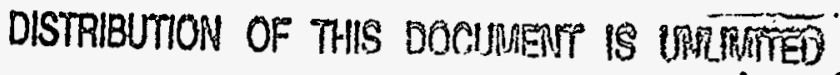

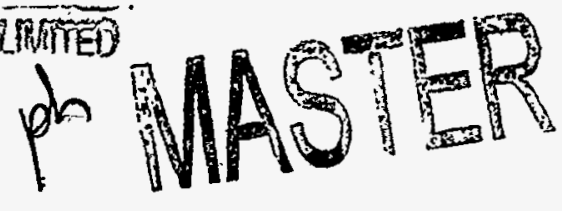




\section{DISCLAIMER}

This report was prepared as an account of work sponsored by an agency of the United States Government. Neither the United States Government nor any agency thereof, nor any of their employees, make any warranty, express or implied, or assumes any legal liability or responsibility for the accuracy, completeness, or usefulness of any information, apparatus, product, or process disclosed, or represents that its use would not infringe privately owned rights. Reference herein to any specific commercial product, process, or service by trade name, trademark, manufacturer, or otherwise does not necessarily constitute or imply its endorsement, recommendation, or favoring by the United States Government or any agency thereof. The views and opinions of authors expressed herein do not necessarily state or reflect those of the United States Government or any agency thereof. 


\section{DISCLANIERR}

Portions of this documerit may be illegible in electronic image proitucts: Images areproduced from the best available origingl document. 


\title{
THERMODYNAMIC STABILITIES OF U(VI) MINERALS: ESTIMATED AND OBSERVED RELATIONSHIPS
}

\author{
ROBERT J. FINCH \\ University of Manitoba, Winnipeg, Manitoba, R3T 2N2, Canada \\ Present address: Argonne National Laboratory, 9700 South Cass Ave., Argonne, IL 60439
}

\begin{abstract}
Gibbs free energies of formation $\left(\Delta \mathrm{G}_{f}^{\circ}\right)$ for several structurally related U(VI) minerals are estimated by summing the Gibbs energy contributions from component oxides. The estimated $\Delta \mathrm{G}^{\circ}{ }_{f}$ values are used to construct activity-activity (stability) diagrams, and the predicted stability fields are compared with observed mineral occurrences and reaction pathways. With some exceptions, natural occurrences agree well with the mineral stability fields estimated for the systems $\mathrm{SiO}_{2}-\mathrm{CaO}-\mathrm{UO}_{3}-\mathrm{H}_{2} \mathrm{O}$ and $\mathrm{CO}_{2}-\mathrm{CaO}-\mathrm{UO}_{3}-\mathrm{H}_{2} \mathrm{O}$, providing confidence in the estimated thermodynamic values. Activity-activity diagrams are sensitive to small differences in $\Delta \mathrm{G}_{f}^{\circ}$ values, and mineral compositions must be known accurately, including structurally bound $\mathrm{H}_{2} \mathrm{O}$. The estimated $\Delta \mathrm{G}_{f}^{\circ}$ values are not considered reliable for a few minerals for two major reasons: (1) the structures of the minerals in question are not closely similar to those used to estimate the $\Delta \mathrm{G}_{f}^{*}$ values of the component oxides, and/or (2) the minerals in question are exceptionally fine grained, leading to large surface energies that increase the effective mineral solubilities.
\end{abstract}

\section{INTRODUCTION}

The thermodynamic stabilities of uranium(VI) minerals are of interest for understanding the role of these minerals in controlling uranium concentrations in oxidizing groundwaters associated with uranium ore bodies, uranium mining and mill tailings and geological repositories for nuclear waste. Unfortunately, few thermodynamic data are available for these minerals, and the large number of $U(V I)$ minerals makes the experimental determination of thermochemical data daunting. However, if the compositions of these minerals are accurately known, the Gibbs free energies of formation may be calculated by using the method of Tardy and Garrels [1], in which the estimated $\Delta \mathrm{G}_{f}^{\circ}$ value for each mineral is the arithmetic sum of the constituent oxide contributions.

This method provides a straightforward way to estimate $\Delta G_{f}^{\circ}$ values; however the confidence in the estimates is uncertain without an independent check on the estimated values. We can use the estimated $\Delta \mathrm{G}_{f}^{\circ}$ values to construct activity-activity diagrams (also called "stability" diagrams) and compare the estimated stability fields with reaction pathways and mineral relationships observed in Nature. Thus natural occurrences are used to support (or refute) the estimated $\Delta \mathrm{G}_{f}^{\circ}$ values.

Two systems are analyzed in detail: $\mathrm{SiO}_{2}-\mathrm{UO}_{3}-\mathrm{CaO}-\mathrm{H}_{2} \mathrm{O}$ and $\mathrm{CO}_{2}-\mathrm{UO}_{3}-\mathrm{CaO}-\mathrm{H}_{2} \mathrm{O}$. The $\mathrm{SiO}_{2-}$ and $\mathrm{CO}_{2}$-bearing system are important in Nature, and the uranyl silicates and uranyl carbonates have been identified as potentially important U(VI) alteration phases of U-bearing waste forms [2,3]. The mobility of $U(V I)$ in carbonate groundwaters is potentially high, as uranyl-carbonate complexes are generally quite stable in solution [4]. The uranyl carbonate 


\section{DISCLAIMIER}

Portions of this document may be illegible in electronic image products. Images-are produced from the best available original document. 
minerals tend to be soluble, and the geochemical conditions under which these minerals precipitate is of interest for understanding the geochemical controls on $U$ transport [5]. Dissolved silica is an important constituent of natural groundwaters, where it occurs predominantly as orthosilicic acid, $\mathrm{H}_{4} \mathrm{SiO}_{4}$, below approximately $\mathrm{pH}=9$ [6]. The concentration of $\mathrm{H}_{4} \mathrm{SiO}_{4}$ in most groundwaters is limited by the precipitation of amorphous silica, which occurs where $\left\{\mathrm{H}_{4} \mathrm{SiO}_{4}\right\}=$ $10^{-2.7} \mathrm{~mol}^{-1 \text { liter }} \mathrm{r}^{-1}$ [6]. The Ca-containing systems are considered because $\mathrm{Ca}$ is virtually ubiquitous in near-surface groundwaters, and many Ca-bearing uranyl minerals are known, representing a variety of near-surface environments. Fortunately, thermodynamic data are available for several of these minerals. The uranyl phosphates are also important in natural waters $[7,8,9]$; however, no uranyl phosphates have been identified from experimental studies of U-bearing waste forms.

\section{CALCULATED FREE ENERGY VALUES}

Tardy and Garrels [1] describe a method for estimating the Gibbs free energies of formation for oxides, hydroxides and layer silicates, including clay minerals $[1,10,11]$. The method is straightforward: Given the $\Delta \mathrm{G} f^{\circ}$ values for stoichiometrically simple oxides and hydroxides, one may estimate the contribution of the constituent oxides to the total $\Delta \mathrm{G}_{f}^{\circ}$ value of each mineral; that is, the $\Delta \mathrm{G}_{f}^{*}$ of each oxide in the mineral structure. The $\Delta \mathrm{G}_{f}^{\circ}$ value of the mineral is the arithmetic sum of the oxide contributions:

$$
\Delta \mathrm{G}_{f}{ }^{0}=\Sigma \Delta \mathrm{G}_{f}{ }^{*} \mathrm{i} .
$$

In this study, the oxide components in the structures of the uranyl minerals are indicated with an asterisk: $\mathrm{UO}_{3}{ }^{*}, \mathrm{CaO}^{*}, \mathrm{SiO}_{2}{ }^{*}, \mathrm{CO}_{2}{ }^{*}$ and $\mathrm{H}_{2} \mathrm{O}$.

The $\Delta \mathrm{G}_{f}^{*}$ values of $\mathrm{UO}_{3} *$ and $\mathrm{H}_{2} \mathrm{O}^{*}$ are calculated by using the data for the $\mathrm{UO}_{3}$ oxyhydroxides, including (meta)schoepite and dehydrated schoepite [12] [The phase synthesized by O'Hare et al. [12] was probably metaschoepite, based on the temperature of synthesis $\left(\sim 50^{\circ} \mathrm{C}\right)$ as well as the composition (see [13]). For this reason, the stoichiometry for metaschoepite, $\mathrm{UO}_{3} \cdot 2 \mathrm{H}_{2} \mathrm{O}$ is used in the calculations in this paper. The experimentally determined $\Delta \mathrm{G}_{f}^{\circ}$ values for several $\mathrm{UO}_{3}$ oxy-hydroxides [12], when plotted as a

Table I. Calculated $\Delta \mathrm{G} f *$ values for component oxides $\left(\mathrm{kJ} \cdot \mathrm{mol}^{-1}\right.$ )

\begin{tabular}{|ll|}
\hline $\mathrm{UO}_{3}{ }^{*}$ & -1153.5 \\
$\mathrm{H}_{2} \mathrm{O}^{*}$ & -242.6 \\
$\mathrm{CaO}^{*}$ & -716.4 \\
$\mathrm{SiO}_{2}{ }^{*}$ & -865.9 \\
$\mathrm{CO}_{2}{ }^{*}$ & -404.6 \\
\hline
\end{tabular}

$$
\begin{gathered}
2 \mathrm{UO}_{3} *+\mathrm{SiO}_{2} *+2 \mathrm{H}_{2} \mathrm{O} * \\
-2 \mathrm{UO}_{3} *-2 \mathrm{H}_{2} \mathrm{O}^{*}
\end{gathered}
$$
function of total water content, define a straight line. A least-squares fit to these data is used to estimate the $\Delta \mathrm{G}_{f}^{*}$ contribution by $\mathrm{H}_{2} \mathrm{O}^{*}$ and $\mathrm{UO}_{3} *$ in the $\mathrm{UO}_{3}$ oxy-hydroxides. The slope of the least-squares-fit line is equal to $\Delta \mathrm{G}_{f}^{*}$ for structurally bound water (i.e., $\mathrm{H}_{2} \mathrm{O}^{*}$, without regard to whether it occurs in the structure as $\mathrm{OH}^{-}$or $\mathrm{H}_{2} \mathrm{O}$ ), and the $\Delta \mathrm{G}_{f}{ }^{*}$ value for anhydrous $\mathrm{UO}_{3}{ }^{*}$ is given by the intercept at $\mathrm{H}_{2} \mathrm{O}=0$. The derived $\Delta \mathrm{G}_{f}^{*}$ values for $\mathrm{H}_{2} \mathrm{O}^{*}$ and $\mathrm{UO}_{3}{ }^{*}$ are given in Table $\mathrm{I}$. The value for $\mathrm{SiO}_{2} *$ is calculated by subtracting the $\Delta \mathrm{G}_{f}{ }^{*}$ values for $\mathrm{H}_{2} \mathrm{O}^{*}$ and $\mathrm{UO}_{3}{ }^{*}$ from $\Delta \mathrm{G}_{f}{ }^{\circ}$ for soddyite [14].

\begin{tabular}{cc}
$2 \mathrm{UO}_{3}^{*}+\mathrm{SiO}_{2} *+2 \mathrm{H}_{2} \mathrm{O}^{*}$ & $\Delta \mathrm{G}_{f}^{\circ}$ soddyite \\
$-2 \mathrm{UO}_{3} *-2 \mathrm{H}_{2} \mathrm{O}^{*}$ & $-2\left(\Delta \mathrm{G}_{f} \mathrm{UO}_{3}{ }^{*}\right)-2\left(\Delta \mathrm{G}_{f} \mathrm{H}_{2} \mathrm{O}^{*}\right)$ \\
\hline $\mathrm{SiO}_{2}{ }^{*}$ & $\Delta \mathrm{G}_{f} \mathrm{SiO}_{2}{ }^{*}$
\end{tabular}


The value of $\Delta \mathrm{G}_{f}^{*}$ for $\mathrm{CaO}^{*}$ is then calculated from uranophane, $\mathrm{Ca}\left(\mathrm{UO}_{2}\right)_{2}\left(\mathrm{SiO}_{3} \mathrm{OH}\right)_{2}\left(\mathrm{H}_{2} \mathrm{O}\right)_{5}$ [14].

\begin{tabular}{cc}
$\mathrm{CaO}^{*}+2 \mathrm{UO}_{3} *+2 \mathrm{SiO}_{2}^{*}+6 \mathrm{H}_{2} \mathrm{O} *$ & $\Delta \mathrm{G}_{f}^{\circ}$ uranophane \\
$-2 \mathrm{UO}_{3}^{*}-2 \mathrm{SiO}_{2}^{*}-6 \mathrm{H}_{2} \mathrm{O}^{*}$ & $-2\left(\Delta \mathrm{G}_{f} \mathrm{UO}_{3}^{*}\right)-2\left(\Delta \mathrm{G}_{f} \mathrm{siO}_{2}^{*}\right)-6\left(\Delta \mathrm{G}_{f} \mathrm{H}_{2} \mathrm{O}^{*}\right)$ \\
\hline $\mathrm{CaO} *$ & $\Delta \mathrm{G}_{f} \mathrm{CaO}^{*}$
\end{tabular}

Two uranyl carbonates (Table II) are used to determine $\Delta \mathrm{G}_{\mathrm{f}} \mathrm{CO}_{3} *$ by using the experimental solubilities of rutherfordine [15] and liebigite [5], respectively. The previously determined $\Delta \mathrm{G}_{f}^{*}$ values for $\mathrm{H}_{2} \mathrm{O} *$ and $\mathrm{UO}_{3} *$ (Table $\mathrm{I}$ ) gives $\Delta \mathrm{G}_{f} \mathrm{CO}_{3} *$ :

\begin{tabular}{cc}
$\mathrm{UO}_{3} *+\mathrm{CO}_{2}{ }^{*}$ & $\Delta \mathrm{G}_{f}^{\circ}$ rutherfordine \\
$-\mathrm{UO}_{3}{ }^{*}$ & $-\Delta \mathrm{G}_{f} \mathrm{UO}_{3}{ }^{*}$ \\
\hline $\mathrm{CO}_{2}{ }^{*}$ & $\Delta \mathrm{G}_{\mathrm{f}} \mathrm{CO}_{2}{ }^{*}$
\end{tabular}

Table II. Gibbs free energy values used to construct Figs. 1 and $2\left(\mathrm{~kJ} \cdot \mathrm{mol}^{-1}\right)$

\begin{tabular}{|c|c|c|c|c|}
\hline MINERAL & FORMULA & $\Delta \mathbf{G}_{f}^{\circ}$ & $\mathbf{M} / \mathbf{C}^{\dagger}$ & REF \\
\hline schoepite & {$\left[\left(\mathrm{UO}_{2}\right)_{8} \mathrm{O}_{2}(\mathrm{OH})_{12}\right]\left(\mathrm{H}_{2} \mathrm{O}\right)_{12}$} & -14045.8 & C & [16] \\
\hline metaschoepite & {$\left[\left(\mathrm{UO}_{2}\right)_{8} \mathrm{O}_{2}(\mathrm{OH})_{12}\right]\left(\mathrm{H}_{2} \mathrm{O}\right)_{10}$} & -13092.1 & M & {$[12]$} \\
\hline$D S^{*}$ & {$\left[\left(\mathrm{UO}_{2}\right) \mathrm{O}_{0.25-0.1}(\mathrm{OH})_{1.5-1.8}\right]$} & -1362.3 & $M$ & [12] \\
\hline becquerelite & $\mathrm{Ca}\left[\left(\mathrm{UO}_{2}\right)_{6} \mathrm{O}_{4}(\mathrm{OH})_{6}\right]\left(\mathrm{H}_{2} \mathrm{O}\right)_{8}$ & -10305.8 & C & [17] \\
\hline "Ca-protasite" & $\mathrm{Ca}_{2}\left[\left(\mathrm{UO}_{2}\right)_{6} \mathrm{O}_{6}(\mathrm{OH})_{4}\right]\left(\mathrm{H}_{2} \mathrm{O}\right)_{8}$ & -10779.6 & C & \\
\hline metacalciouranoite & $\mathrm{Ca}_{3}\left[\left(\mathrm{UO}_{2}\right)_{6} \mathrm{O}_{8}(\mathrm{OH})_{2}\right]\left(\mathrm{H}_{2} \mathrm{O}\right)_{6}$ & -10768.3 & C & \\
\hline calciouranoite & $\mathrm{Ca}_{3}\left[\left(\mathrm{UO}_{2}\right)_{6} \mathrm{O}_{8}(\mathrm{OH})_{2}\right]\left(\mathrm{H}_{2} \mathrm{O}\right)_{9}$ & -11496.1 & C & \\
\hline soddyite & $\left(\mathrm{UO}_{2}\right)_{2} \mathrm{SiO}_{4}\left(\mathrm{H}_{2} \mathrm{O}\right)_{2}$ & -3658.0 & M & [14] \\
\hline swamboite & $\left(\mathrm{UO}_{2}\right)\left[\left(\mathrm{UO}_{2}\right)\left(\mathrm{SiO}_{3} \mathrm{OH}\right)\right]_{6}\left(\mathrm{H}_{2} \mathrm{O}\right)_{30}$ & -21092.4 & C & {$[17]$} \\
\hline uranosilite & $\left(\mathrm{UO}_{2}\right)\left(\mathrm{SiO}_{4}\right)_{7}$ & $(-7214.5)$ & $\mathrm{C}$ & {$[17]$} \\
\hline uranophane & $\mathrm{Ca}\left[\left(\mathrm{UO}_{2}\right)\left(\mathrm{SiO}_{3} \mathrm{OH}\right)\right]_{2}\left(\mathrm{H}_{2} \mathrm{O}\right)_{5}$ & -6210.6 & M & {$[14]$} \\
\hline haiweeite & $\mathrm{Ca}\left[\left(\mathrm{UO}_{2}\right)_{2}\left(\mathrm{Si}_{2} \mathrm{O}_{5}\right)_{3}\right]\left(\mathrm{H}_{2} \mathrm{O}\right)_{5}$ & $(-9431.4)$ & C & [18] \\
\hline ursilite & $\mathrm{Ca}_{4}\left[\left(\mathrm{UO}_{2}\right)_{4}\left(\mathrm{Si}_{2} \mathrm{O}_{5}\right)_{5}(\mathrm{OH})_{6}\right]\left(\mathrm{H}_{2} \mathrm{O}\right)_{15}$ & $(-20504.6)$ & C & [18] \\
\hline rutherfordine & $\mathrm{UO}_{2} \mathrm{CO}_{3}$ & -1563.1 & M & [15] \\
\hline joliotite & $\mathrm{UO}_{2} \mathrm{CO}_{3}\left(\mathrm{H}_{2} \mathrm{O}\right)_{1-2}$ & -2043.3 & c & [17] \\
\hline sharpite & $\mathrm{Ca}\left(\mathrm{UO}_{2}\right)_{6}\left(\mathrm{CO}_{3}\right)_{5}(\mathrm{OH})_{4}\left(\mathrm{H}_{2} \mathrm{O}\right)_{3}$ & -11601.1 & C & [17] \\
\hline fontanite & $\mathrm{Ca}\left(\mathrm{UO}_{2}\right)_{3}\left(\mathrm{CO}_{3}\right)_{4}\left(\mathrm{H}_{2} \mathrm{O}\right)_{3}$ & -6523.1 & C & [19] \\
\hline urancalcarite & $\mathrm{Ca}\left(\mathrm{UO}_{2}\right)_{2}\left(\mathrm{CO}_{3}\right)(\mathrm{OH})_{6}\left(\mathrm{H}_{2} \mathrm{O}\right)_{3}$ & -6037.0 & C & {$[17]$} \\
\hline zellerite & $\mathrm{Ca}\left(\mathrm{UO}_{2}\right)\left(\mathrm{CO}_{3}\right)_{2}\left(\mathrm{H}_{2} \mathrm{O}\right)_{3}$ & $(-3892.1)$ & C & [17] \\
\hline liebigite & $\mathrm{Ca}_{2}\left(\mathrm{UO}_{2}\right)\left(\mathrm{CO}_{3}\right)_{3}\left(\mathrm{H}_{2} \mathrm{O}\right)_{10}$ & $(-6226.0)$ & $M$ & {$[5]$} \\
\hline
\end{tabular}

${ }^{\dagger} \mathrm{M} / \mathrm{C}$ indicates measured or calculated values. ${ }^{\circ} \mathrm{DS}=$ dehydrated schoepite; the $\Delta \mathrm{G}^{\circ}{ }_{\mathrm{f}}$ value cited corresponds to $\mathrm{UO}_{3} \cdot 0.85 \mathrm{H}_{2} \mathrm{O}$ [12]. Metaschoepite $\left(=\mathrm{UO}_{3} \cdot 2 \mathrm{H}_{2} \mathrm{O}\right)$ is used for all reactions; the structural formula is inferred [16]. References refer to reported $\Delta G^{\circ}{ }_{f}$ values where available; for phases with calculated $\Delta \mathrm{G}^{\circ}$, values, references refer to the formula cited. Values in parentheses are not considered reliable (see text). 
The value of $\Delta \mathrm{G}_{\mathrm{f}} \mathrm{CaO} *$ determined from liebigite is the same as that determined from the uranophane data, reflecting the similar structural roles of $\mathrm{Ca}$ in the structures of uranophane and liebigite. In fact, the structural role of $\mathrm{Ca}$ is similar in most of the uranyl minerals for which crystal structures are known [20]. This also suggests a similar free energy contribution by $\mathrm{CO}_{2}{ }^{*}$ in the structures of these two uranyl carbonates.

The values for these five hypothetical oxides are used to estimate $\Delta \mathrm{G}_{f}^{\circ}$ for various uranyl minerals by adding the contributions from the constituent oxides in their stoichiometric proportions. The $\Delta \mathrm{G} f^{\circ}$ values thus calculated are listed in Table $I$, along with the structural formulas of the minerals considered in this study. The $\Delta \mathrm{G} f^{\circ}$ values for all dissolved species, as well as calcite and $\mathrm{CO}_{2}$, used for the construction of the activity-activity diagrams are taken from Grenthe et al. [4].

\section{RESULTS}

Activity-activity diagrams illustrate the stabilty fields occupied by solid phases in equilibrium with an aqueous phase. The underlying assumption of these diagrams is that the concentration of dissolved $U$ is sufficient to stabilize the solids. This is also implicit in the way that the equilibrium reactions are written: all $\mathrm{U}$ is conserved in the solids.

\section{System $\mathrm{CO}_{2}-\mathrm{CaO}-\mathrm{UO}_{3}-\mathrm{H}_{2} \mathrm{O}$}

Calculated with the $\Delta G_{f}^{\circ}$ values from Table II, Fig. 1 illustrates the stability fields for several uranyl carbonate minerals. The concentration of $\mathrm{Ca}$ in many groundwaters is controlled by equilibrium with calcite, $\mathrm{CaCO}_{3}$, and dissolved $\mathrm{CO}_{2(\mathrm{~g})}$ :

$$
\mathrm{CaCO}_{3}+2 \mathrm{H}+\Leftrightarrow \mathrm{Ca}^{2+}+\mathrm{H}_{2} \mathrm{O}+\mathrm{CO}_{2(\mathrm{~g})}
$$

This equilibrium is indicated as a diagonal dotted line in Fig. 1. The composition of water in equilibrium with calcite will plot on this line. Also shown in Fig. 1 is the partial pressure of $\mathrm{CO}_{2}$ for waters open to the atmosphere (horizontal dotted line: $\mathrm{PCO}_{2}=10^{-3.5} \mathrm{~atm}$ ). The composition of a groundwater, open to the atmosphere and in equilibrium with calcite, will plot at the intersection of the two dotted lines in Fig. 1. Notably, this falls within the stability field of becquerelite, the most common uranyl oxide hydrate mineral in Nature [21].

The calcite equilibrium line passes through the fields for becquerelite, schoepite and rutherfordine, the most common minerals among those represented in Fig. 1, and rutherfordine is by far the most common uranyl carbonate [21]. The other carbonates, fontanite, sharpite and urancalcarite are relatively rare. These occur where $\mathrm{PCO}_{2}$ values reach quite high values, usually where calcite equilibrium does not control groundwater chemistries. In fact, of the three uranyl carbonates that lie above the calcite line in Fig. 1, sharpite and urancalcarite are rare and occur in deposits where the predominant carbonate mineral in the host rocks is magnesian calcite or dolomite [22]. Fontanite, which coexists with becquerelite and uranophane, occurs in pelitic silts and shales [19].

Two uranyl carbonates are not shown in Fig. 1: liebigite and zellerite (Table II). The stability fields calculated for these two minerals replace most of the area shown in Fig. 1, contrary to observation. Liebigite and zellerite are commonly found as efflorescences on mine walls, surface outcrops, and elsewhere that evaporation is high. These minerals tend to be extremely fine grained, and this contributes to the surface free energy of the minerals. It is 


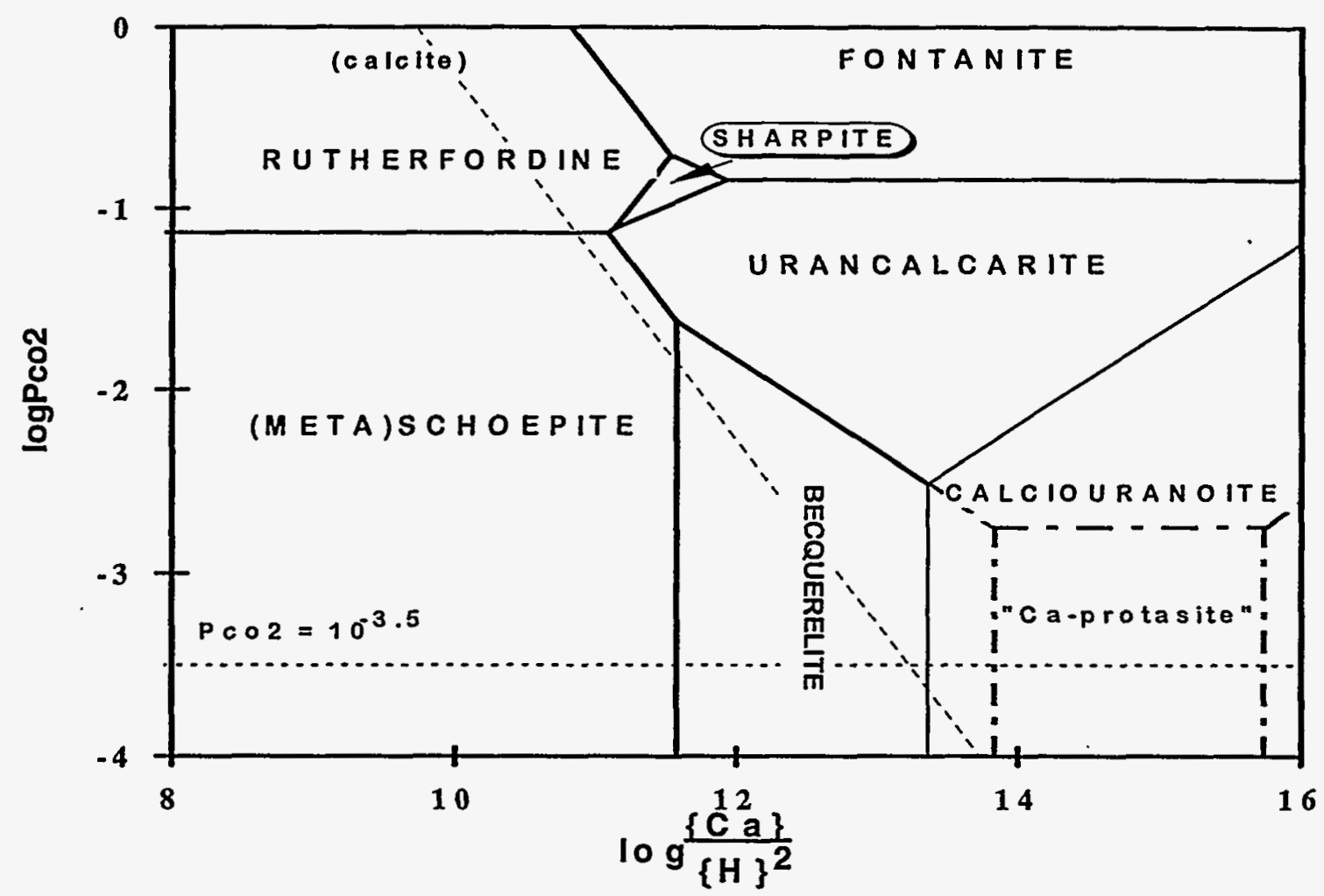

Figure 1. Activity-activity diagram for the system $\mathrm{CO}_{2}-\mathrm{CaO}-\mathrm{UO}_{3}-\mathrm{H}_{2} \mathrm{O}$, calculated by using estimated $\Delta \mathrm{G}_{f}^{\circ}$ values from the mineral formulas in Table II (empirical $\Delta \mathrm{G}_{f}^{\circ}$ values used for metaschoepite and rutherfordine). Lines dashed where metastable. Diagonal dotted line is calcite equilibrium (see text). $\mathrm{PCO}_{2}$ value for water open to the atmosphere is shown by horizontal dotted line $\left(\mathrm{PCO}_{2}=10^{-3.5}\right)$.

unlikely that significant structural strain exists in the structure of liebigite, as well-formed crystals are known, however, some degree of supersaturation may be required to precipitate liebigite under most geochemical conditions. Similar arguments can be made for the lack of agreement between the estimated stability range of zellerite and known natural occurrences. On the other hand, neither mineral bears a close structural similarity to the other carbonates, which are all based on structural sheets. The structure of liebigite consists of isolated clusters of $\left(\mathrm{UO}_{2}\right)\left(\mathrm{CO}_{3}\right)_{3}$ groups; the structure of zellerite is unknown.

\section{System $\mathrm{SiO}_{2}$ - $\mathrm{CaO}-\mathrm{UO}_{3}-\mathrm{H}_{2} \mathrm{O}$}

Figure 2 illustrates the stability fields of minerals common in Si-bearing groundwaters. The most common $\mathrm{Pb}$-free U(VI) minerals are schoepite, becquerelite, soddyite, uranophane and rutherfordine. Schoepite forms early in the alteration paragenesis of uraninite oxidation products. Though common, schoepite is not usually abundant at most oxidized uranium deposits [7,21]. This is because schoepite is commonly replaced by uranyl silicates and carbonates, especially uranophane, soddyite and rutherfordine [7,21,23,24,25]. Although the direct replacement of schoepite by becquerelite is not readily confirmed in Nature, this reaction has been reported from several experimental studies $[26,27,28]$. The stability field shown for schoepite probably represents a maximum. Schoepite commonly forms fine-grained masses, effectively increasing schoepite solubility. Schoepite dehydrates spontaneously, becoming polycrystalline $[23,29]$. The lower hydrates also have higher solubilities in water at $\sim 25^{\circ} \mathrm{C}[12]$. 


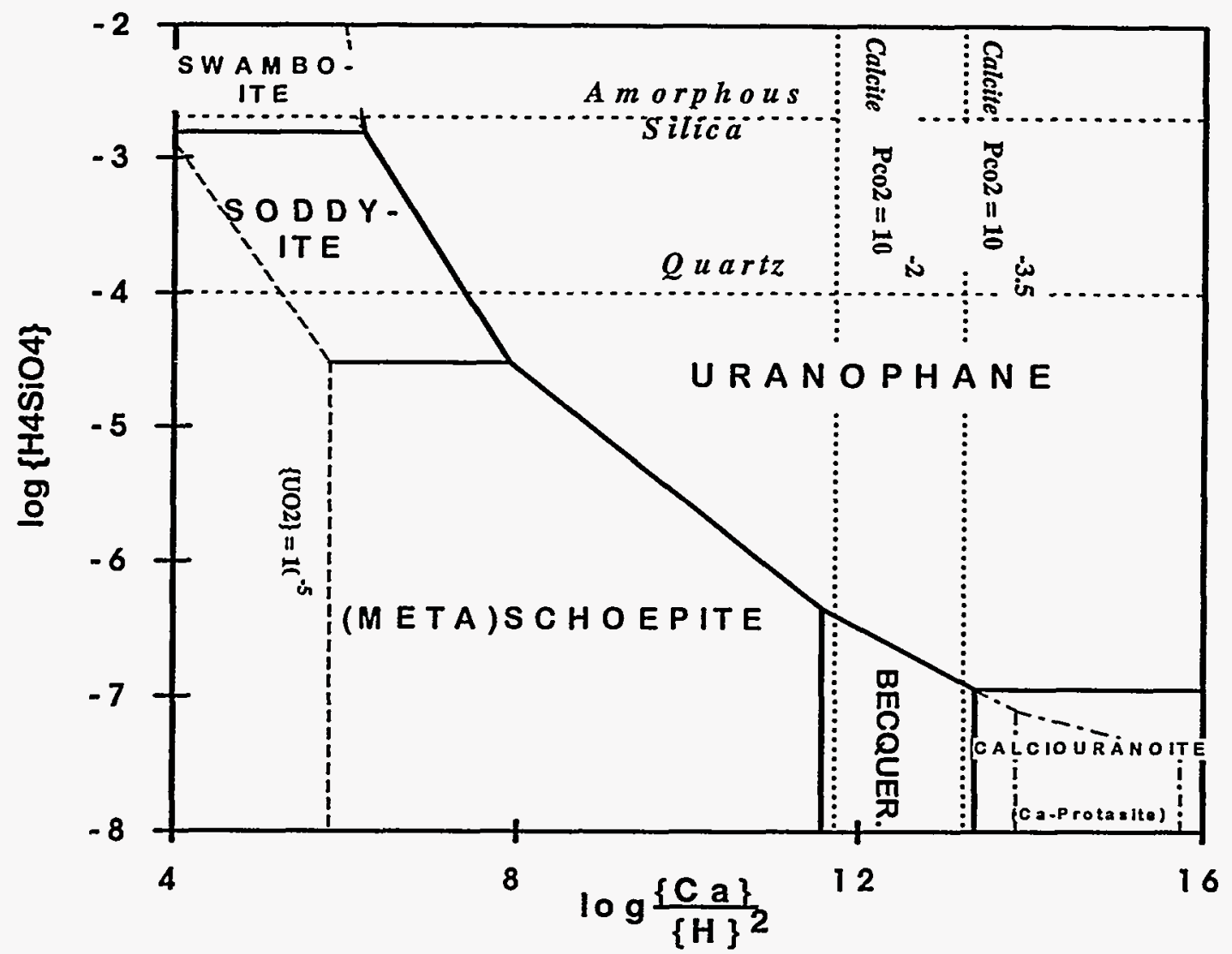

Figure 2. Activity-activity diagram for the system $\mathrm{SiO}_{2}-\mathrm{CaO}-\mathrm{UO}_{3}-\mathrm{H}_{2} \mathrm{O}$, calculated by using estimated $\Delta \mathrm{G}_{f}^{\circ}$ values from the mineral formulas in Table II (empirical $\Delta \mathrm{G}_{f}^{\circ}$ values are used for metaschoepite, rutherfordine, uranophane and soddyite). Lines dashed where metastable. Horizontal lines are equilibria with silica; vertical dotted lines represent calcite equilibrium for $\mathrm{PCO}_{2}$ values for water open to the atmosphere $\left(\mathrm{PCO}_{2}=10^{-3.5}\right)$ and for a typical water-saturated soil $\left(\mathrm{PCO}_{2} \cong 10^{-2}\right)[6]$. BECQUER. = becquerelite.

Uranophane is the most common U(VI) mineral in Nature [30]. This observation is consistentwith the large field of stability indicated in Fig. 2, as well as the fact that uranophane is the stable U(VI) mineral in contact with groundwaters whose compositions are controlled by calcite and silica equilibria [31]. Soddyite is another common mineral in oxidized U deposits, where it replaces schoepite and, less commonly, replaces uranophane (due to interaction with dilute meteoric waters [24]).

The rare mineral swamboite commonly occurs with soddyite and uranophane [22], suggesting a genetic relationship. According to Fig. 2, swamboite forms near the upper limit for $\left\{\mathrm{H}_{4} \mathrm{SiO}_{4}\right\}$ in natural waters. The extremely rare mineral, calciouranoite defines a stability field in Si-poor waters at high values of $\mathrm{pH}$ and/or dissolved Ca. This is consistent with reports of the occurrences for calciouranoite and metacalciouranoite [18]. The stability field for calciouranoite represents a maximum, and assumes coarsely crystalline material. In fact, calciouranoite is always cryptocrystalline, and the small grain size will contribute to the surface free energy, increasing its solubility and decreasing its field of stability. The small grain size of calciouranoite is probably due to strain caused by structural limitations on the ability of the uranyl oxide hydrate sheets to accommodate a large amount of interlayer $\mathrm{Ca}$ atoms [24]; the same effect may explain the apparent lack of the hypothetical mineral, "Ca-protasite" in Nature (it is known only as a 
synthetic phase). In practice, becquerelite may well replace most of these fields, as suggested by the formation of synthetic becquerelite in Ca-rich solutions [26,27,28].

The stability field for becquerelite is approximately bounded by the $\{\mathrm{Ca}\} /\{\mathrm{H}\}^{2}$ values defined by a range of $\mathrm{PCO}_{2}$ values common for waters in equilibrium with calcite, from water open to the air to water-saturated soils $\left(10^{-3.5} \leq \mathrm{PCO}_{2} \leq 10^{-2}\right)$ [6]. Thus, although the stability field for becquerelite appears relatively small compared to that of schoepite in Fig. 2 , it falls within the expected range of compositions for most Si-poor near-surface groundwaters. This is why becquerelite is more abundant than schoepite at most oxidized $U$ deposits [21].

Not shown in Fig. 2 are the stability fields estimated for the three uranyl silicates, haiweeite, uranosilite and ursilite (Table II). The stability fields of these three minerals, when estimated with the $\Delta \mathrm{G}_{f}^{*}$ values in Table $\mathrm{I}$, replace the entire field of uranophane illustrated in Fig. 1, contrary to observation. Haiweeite, uranosilite and ursilite always form as fine-grained masses, and surface-free energy must contribute to the increased solubilities of these minerals. However, though the structures of these minerals remain unknown, they are not structurally related to uranophane or soddyite. Haiweeite and ursilite are probably structurally related to weeksite [18]. The structure of the rare mineral uranosilite is also unknown, and is probably unique among the uranyl silicates. All three minerals are probably based on a framework of $\mathrm{SiO}_{4}$ tetrahedra, rather than isolated $\mathrm{SiO}_{4}$ tetrahedra as in uranophane and soddyite. Therefore, the estimate of $\Delta \mathrm{G}_{\mathrm{S}} \mathrm{SiO}_{2}{ }^{*}$ derived from soddyite is not appropriate for estimating the contribution of silica to the Gibbs free energy of these minerals.

\section{SUMMARY AND CONCLUSIONS}

The uranyl minerals whose stability fields are illustrated in Figures 1 and 2 have several features in common: (1) There is little compositional variation observed for uranyl minerals formed during weathering $\left(\sim 20-40^{\circ} \mathrm{C}\right)$; these minerals tend to be well defined compositionally [24]; (2) The uranyl minerals represented in Figures 1 and 2 commonly occur as well-formed crystals; estimates of $\Delta \mathrm{G}_{f}^{\circ}$ values for poorly crystalline or very fine-grained minerals tend to be inconsistent with the natural occurrences; (3) the structures of these phases are related. Most are sheet structures, based on polymerized $U$ polyhedra $[20,32,33]$. The unique role of $U^{6+}$ in most of these minerals suggests that the $\Delta \mathrm{G}_{f}^{*}$ contributions of $\mathrm{UO}_{3} *$ to $\Delta \mathrm{G}_{f}{ }^{\circ}$ may be similar for a variety of U(VI) minerals.

The method described here for estimating the Gibbs free energies of several structurally related uranyl phases is a potentially powerful tool for helping us better understand the geochemical role of this large family of minerals. With the aid of activity-activity diagrams, the natural occurrences can be used to place constraints on reasonable estimates of $\Delta \mathrm{G}_{f}{ }^{\circ}$ values. However, this method is not a panacea, and it cannot replace accurate thermodynamic determinations. Especially important is the fact that estimates of $\Delta \mathrm{G}_{f}^{\circ}$ values of the constituent oxides in minerals of one structure type are not appropriate for estimating the $\Delta \mathrm{G}_{f}^{\circ}$ values of structurally distinct phases. It is also important to accurately know the compositions of the minerals in question, as even small variations in structurally bound $\mathrm{H}_{2} \mathrm{O}$ can significantly affect estimated $\Delta \mathrm{G}_{f}{ }^{\circ}$ values (see e.g., [12]). This method is best used for estimating $\Delta \mathrm{G}_{f}{ }^{\circ}$ values of minerals for which structural studies have confirmed the compositions. Mineral solubilities can also be strongly influenced by grain size, and most fine-grained mineral will not precipitate under conditions expected (compare with clay minerals). Another drawback to this method is the inability to distinguish among polymorphs. The most important polymorphs in the systems 
described here are alpha-uranophane and beta-uranophane. The stability field shown in Fig. 2 represents alpha-uranophane, but beta-uranophane is important in several oxidized $U$ deposits $[21,25]$. Given these caveats, this method appears useful, especially with the large number of $\mathrm{U}(\mathrm{V})$ minerals that can influence $\mathrm{U}$ transport in oxidizing groundwaters.

\section{ACKNOWLEDGMENTS}

This work was completed at the University of Manitoba during a postdoctoral fellowship from the National Science and Engineering Research Council (Canada). Financial support for the early stages of this work were provided by the Swedish Nuclear Fuel and Waste Management Co. (SKB). Travel funds were generously provided by Argonne National Laboratory.

\section{REFERENCES}

1. Y. Tardy and R.M. Garrels, Geochim. Cosmochim. Acta 41, 1051 (1976).

2. R.J. Finch and R.C. Ewing, SKB Technical Report $91-15$ (SKB, Stockholm) 1991.

3. D.J. Wronkiewicz, J.K. Bates, T.J. Gerding, E. Veleckis and B.S. Tani, J. Nucl. Mater. 190, 107 (1992).

4. I. Grenthe et al. Thermodynamics of Uranium. North-Holland (NY, Amsterdam) (1992) $656 \mathrm{p}$.

5. A.K. Alwan and P.A. Williams, Mineral. Mag. 43, 665 (1980).

6. W. Stumm and J.J. Morgan, Aqueous Chemistry, 2nd Edition, Wiley-Interscience (NY, 1981) 780 p.

7. R.J. Finch and R.C. Ewing, J. Nucl. Mater. 190, 133 (1992).

8. A. Sandino and J. Bruno, Geochim. Cosmochim. Acta 56, 4135 (1992).

9. T. Murakami, T. Ohnuki, H. Isobe and T. Sato, Amer. Mineral. (submitted).

10. Y. Tardy and R.M. Garrels, Geochim. Cosmochim. Acta 42, 87 (1977).

11. Y. Tardy and J. Duplay, Geochim. Cosmochim. Acta 56, 3007 (1992).

12. P.A.G. O'Hare, B.M. Lewis and S.N. Nguyen, J. Chem. Thermodynamics 20, 1287 (1988).

13. R.J. Finch, F.C. Hawthorne and R.C. Ewing in Scientific Basis for Nuclear Waste Management XIX, edited by W.M. Murphy and D.A. Knecht (Mater. Res. Soc. Proc. 412, Pittsburgh, PA, 1996) pp. 361-368.

14. S.N. Nguyen, R.J. Silva, H.C. Weed and J.E. Andrews, J. Chem. Thermodyn. 24, 359 (1992).

15. E.I. Sergeyeva, A.A. Nikitin, I.L. Khodakovkiy and G.B Naumov, Geokhimiya 11, 1340 (1972) [English translation in: Geochem. Internat. 9, 900 (1972)].

16. R.J. Finch, M.A. Cooper, F.C. Hawthorne and R.C. Ewing, Can. Mineral. 34, 1071 (1996).

17. E.H. Nickel and M.C. Nichols, Mineral Reference Manual. Van Norstrand Reinhold (NY) 1992, 250 p.

18. J. Cejka, and Z. Urbanec, Secondary Uranium Minerals. Academia, Czechoslovak Academy of Sciences (Prague, 1990) 93 p.

19. M. Deliens and P. Piret, Eur. J. Mineral. 4, 1271 (1992).

20. P.C. Burns, M.L. Miller, R.C. Ewing, Can. Mineral. 34, 845 (1996).

21. C. Frondel, Systematic mineralogy of uranium and thorium. Geol. Soc. Amer. Bull. 1064 (1958) 399 p.

22. M. Deliens, P. Piret and G. Comblain, Les Minéraux Secondaires d'Uranium du Zaire. Musée Royal de l'Afrique Centrale (Tervuren, 1981) $113 \mathrm{p}$.

23. R.J. Finch, M.L. Miller and R.C. Ewing, Radiochimica Acta 58/59, 433 (1992).

24. R.J. Finch, Ph.D. Thesis, University of New Mexico, 1994.

25. E.C. Pearcy, J.D. Prikryl, W.M. Murphy and B.W. Leslie, Appl. Geochem. 9, 713 (1994).

26. A. Sandino and B. Grambow, Radiochim. Acta 66/67, 37 (1994).

27. R. Vochten and L. Van Havebeke, Mineral. Petrol. 43, 65 (1990).

28. A.G. Sowder, S.B. Clark and R.A. Fjeld, Radiochim. Acta 74, 45 (1996).

29. C.L. Christ and J.R. Clark, Amer. Mineral. 45, 1026 (1960).

30. D.K. Smith, in: Uranium Geochemistry, Mineralogy, Geology, Exploration and Resources, edited by B. DeVivo, F. Ippolito, G. Capaldi \& P.R. Simpson. Instit. Min. Metall., London (1984). pp.43-88.

31. D. Langmuir, Geochim. Cosmochim. Acta 42, 547 (1978).

32. H.T. Evans, Science 141, 154 (1963).

33. M.L. Miller, R.J.Finch, P.C.Burns, and R.C. Ewing, J. Mater. Res. 11, 3048 (1996). 